\title{
Which Firm Characteristics Affect Foreign Analyst Coverage? Evidence from the Taiwan Stock Market
}

\author{
Lie-Huey Wang \\ Department of Finance, Ming Chuan University, Taiwan \\ Email: lhwang@mail.mcu.edu.tw
}

How to cite this paper: Wang, L.-H. (2018) Which Firm Characteristics Affect Foreign Analyst Coverage? Evidence from the Taiwan Stock Market. Journal of Mathematical Finance, 8, 64-85.

https://doi.org/10.4236/jmf.2018.81006

Received: November 3, 2017

Accepted: January 28, 2018

Published: January 31, 2018

Copyright $\odot 2018$ by author and Scientific Research Publishing Inc. This work is licensed under the Creative Commons Attribution International License (CC BY 4.0).

http://creativecommons.org/licenses/by/4.0/

\section{c) (i) Open Access}

\begin{abstract}
This study investigates the association between firm characteristics and foreign analyst coverage. Using a sample of 366 firms listed on the Taiwan Stock Exchange that were followed by foreign analysts from January 2006 to June 2012, I employ the finite Tobit regression mixture model to analyze which firm characteristics influence foreign analyst coverage. The results find that mixture model may express differential influences on analyst coverage based on the heterogeneity of firm characteristics in different subgroups. Price-tobook ratio, firm size, and institutional ownership are the important characteristic variables that influence foreign analyst coverage. Among them, price-tobook ratio and foreign analyst coverage may present an inverted $U$-shaped or a U-shaped correlation in different subgroups. Also, there is an endogenous relationship between foreign analyst coverage and foreign institutional ownership, and thus, the characteristics of target firms followed by foreign analysts resulting from changes in foreign institutional ownership cannot be ignored. Finally, I also find that large-sized firms with high institutional ownership and medium stock turnover rate have the highest probability of being followed by foreign analysts.
\end{abstract}

\section{Keywords}

Analyst Coverage, Price-to-Book Ratio, Firm Size, Institutional Ownership, Finite Mixture Models

\section{Introduction}

Since financial analysts provide information to capital market, they play an important role as information intermediators (Jegadeesh and Kim [1]). The private 
information hypothesis suggests that analysts convey private information from a firm's management to their investors, which can reduce information asymmetry (Jiraporn et al. [2]). The investor recognition hypothesis suggests that analysts are able to disseminate firm-related information to market participants, which helps with investor recognition and awareness of the firms (Altınkilic et al. [3]).

The analyst reports have high information value (Call et al. [4]), and investors believe that the non-financial information in analyst reports are credible and of value for reference (Bradshaw [5]). Therefore, analyst reports are important sources of information for investors making investment decisions (Firth et al. [6]). Huang et al. [7] show that financial analysts' earnings forecast offers reference value. Barber et al. [8] document that stock recommendations and forecast revisions from analysts can result into significant market reactions. Green [9] finds that early access to stock recommendations from analysts provides investors with significant positive abnormal returns. Guerard Jr. et al. [10] report that portfolios constructed with analyst forecast information were rewarded by the global market.

Relevant studies argue that analysts prefer firms with optimistic forecasts. For example, Tehranian et al. [11] find that merged firms with better operating and long term stock performance are more likely to attract analyst attention and following. In addition, Mola et al. [12] suggest that, when selecting target firms to follow, analysts prefer stocks with high investor attention. In general, investors prefer firms with better sales growth forecasts, higher operating cash flow and higher return on assets, and therefore these kinds of firms can contribute to commission fee or underwriting revenues of sell-side security houses and analysts. Jung et al. [13] also indicate that firms with high uncertainty or fluctuation in earnings might reduce the accuracy of analysts' forecasts. As a result, analysts are less inclined to follow such firms. Furthermore, price-to-book ratio is often used as the proxy for a firm's Tobin's Q (Lewellen and Badrinath [14]) and as an indicator of the firm's growth and profitability (Lundholm and Sloan [15]). Also, price-to-book ratio is generally used to measure the price of a stock or as an evaluation of the market (Lakonishok et al. [16]). Wang et al. [17] find that firms followed by foreign analysts are characterized by high price-to-book ratio; however, this study detects significant inverted $\mathrm{U}$-shaped correlation.

Some studies assert that an inadequate internal control system decreases the credibility and quality of a firm's financial information. It is usually more costly to collect information from the firm; hence, analysts are less likely to be attracted to firms with low-quality information. For example, McNichols and O'Brien [18] report that firms with lower credit ratings often experience a decrease in analyst coverage. Young and Peng [19] show that analysts stop following firms before accounting fraud is made public. Clinton et al. [20] demonstrate that analysts are less likely to follow firms with inadequate internal control or adverse opinion audit reports. Chen et al. [21] note that firms with low analyst coverage have more underlying agency problems such as divergence between cash flow and 
voting rights, excess $\mathrm{CEO}$ compensation, value-destroying acquisitions, and earnings management.

Given the above discussion, price-to-book ratio can be used to observe if a firm's stock price is overvalued or undervalued relative to net worth. Popular stocks, such as those of large-sized firms or firms with high stock turnover rate, attract more attentions from investors. Furthermore, firms with better corporate governance which enables the analysts to make more accurate predictions for the firms. As a consequence, it can effectively reduce the reputation risk of sellside security houses and analysts. Previous studies argue that firms' financial characteristics are some of the important factors of analyst coverage, e.g. firm size (Firth et al. [6]), earnings performance (Tehranian et al. [11]), growth (Kadan et al. [22]), and corporate governance (Chen et al. [21]). Because financial statement information is backward-looking, however, analyst reports offer predictive value when it comes to firms' earnings growth. Hence, changes in analyst coverage of firms are early indicators of future fundamentals of firms (Jung et al. [23]). Accordingly, finding the firm characteristics that interest analysts do have high reference value for investors.

As of May 2017, the total amount of foreign investor ownership accounted for approximately $40 \%$ of the total market value of all listed and OTC companies. Therefore, the investment behavior of foreign investors is keenly observed by domestic investors. The reports by foreign analysts are the primary reference for foreign institutional investors to make investment decisions on the Taiwan Stock Market. Consequently, the influences of foreign analyst coverage on investors and the stock market cannot be neglected. Since most prior studies concentrate on the information role of analysts, without much discussion on the preferences of the analysts, this study focuses on the highly influential foreign analyst reports in the Taiwan Stock Market to discuss which characteristics of target firms attract the attention of foreign securities houses and analysts. Understanding what characteristics foreign analysts are interested in as they choose their target stocks will be an extremely valuable reference for investors.

This study contributes to the academic research and practical application as follows. 1) This study analyzes whether the firms followed by analysts have certain characteristics from the perspectives of foreign analysts. This issue is rarely discussed in previous studies and can offer a new way of thinking about the role of sell-side analysts in the capital market in terms of private information and investor recognition. 2) Finding out which important firm characteristics analysts are concern about will be of valuable reference to investors. This study helps to find the firm characteristics targeted by foreign analysts, and reduce investor loss due to investment behavior biases.

The remainder of this paper is organized as follows. Section 2 introduces a sample construction, describes variable definitions and the econometric method, and outlines the empirical model design. Section 3 reports the interpretations of the results. Section 4 illustrates the robustness tests and discussion. Finally, Section 5 presents the conclusions of this study and suggestions for further studies. 


\section{Data and Method}

\subsection{Data}

The empirical analyses are carried out on a panel dataset of 366 listed companies in the Taiwan Stock Exchange from January 2006 to June 2012. The sample excludes firms from the financial industry and those which were delisted after 2012. The data of foreign analyst reports come from the Eikon database of Thomson Reuters. I downloaded the original PDF files of foreign analyst reports provided by forty-five foreign security houses, and built empirical data manually. The firms' financial statements and corporate governance data are obtained from Taiwan Economic Journal Company (TEJ).

Table 1 presents the distribution of foreign analyst reports by industries. It indicates that the number of foreign analyst reports increases over the years, growing from 2754 reports in 2006 to 6269 reports in 2011. As a whole, about $70 \%$ of the foreign analyst reports are related to electronic and biotechnological firms, meaning that foreign analysts pay close attention to the electronic and biotechnological industries in Taiwan.

\subsection{Variables}

In this study, intensity of foreign analyst reports serves as a proxy for foreign analyst coverage (Wang et al. [17]), measured by the natural logarithm of the number of foreign analyst reports for a firm in a given period. Following extant literature, the independent variables include price-to-book ratio (Wang et al. [17]), firm size (Hsieh et al. [24]), profitability (Mola et al. [12]), financial leverage (Moses [25]), investors' attention or stock liquidity (Mola et al. [12]), and institutional ownership (Arand et al. [26]) that may affect a firm's analyst followings. Price-to-book ratio is measured by stock price per share divided by net assets per share. The preliminary tests show that three proxy variables for firm size-market value, ordinary share capital and total assets, significantly influence foreign analyst coverage. Taking into account that market value and ordinary share capital might have collinearity with price-to-book ratio and stock turnover

Table 1. The distribution of foreign analyst reports by industry.

\begin{tabular}{|c|c|c|c|c|c|c|c|c|}
\hline Industry & 2006 & 2007 & 2008 & 2009 & 2010 & 2011 & 2012Q2 & $\begin{array}{c}\text { Total foreign } \\
\text { analyst reports }\end{array}$ \\
\hline $\begin{array}{l}\text { Electronic } \\
\text { industry }\end{array}$ & $\begin{array}{c}2125^{\dagger} \\
(77.16 \%)\end{array}$ & $\begin{array}{c}3208 \\
(76.31 \%)\end{array}$ & $\begin{array}{c}3405 \\
(72.12 \%)\end{array}$ & $\begin{array}{c}3390 \\
(74.54 \%)\end{array}$ & $\begin{array}{c}3652 \\
(68.98 \%)\end{array}$ & $\begin{array}{c}4305 \\
(68.67 \%)\end{array}$ & $\begin{array}{c}1242 \\
(75.87 \%)\end{array}$ & $\begin{array}{c}21237 \\
(72.39 \%)\end{array}$ \\
\hline $\begin{array}{l}\text { Biotechnology } \\
\text { industry }\end{array}$ & $\begin{array}{c}25 \\
(0.91 \%)\end{array}$ & $\begin{array}{c}20 \\
(0.48 \%)\end{array}$ & $\begin{array}{c}23 \\
(0.49 \%)\end{array}$ & $\begin{array}{c}62 \\
(1.36 \%)\end{array}$ & $\begin{array}{c}81 \\
(1.53 \%)\end{array}$ & $\begin{array}{c}105 \\
(1.68 \%)\end{array}$ & $\begin{array}{c}16 \\
(0.98 \%)\end{array}$ & $\begin{array}{c}332 \\
(1.13 \%)\end{array}$ \\
\hline Others & $\begin{array}{c}604 \\
(21.93 \%)\end{array}$ & $\begin{array}{c}976 \\
(23.21 \%)\end{array}$ & $\begin{array}{c}1293 \\
(27.39 \%)\end{array}$ & $\begin{array}{c}1096 \\
(24.10 \%)\end{array}$ & $\begin{array}{c}1561 \\
(29.49 \%)\end{array}$ & $\begin{array}{c}1859 \\
(29.65 \%)\end{array}$ & $\begin{array}{c}379 \\
(23.15 \%)\end{array}$ & $\begin{array}{c}7768 \\
(26.48 \%)\end{array}$ \\
\hline $\begin{array}{l}\text { Total foreign } \\
\text { analyst reports }\end{array}$ & 2754 & 4204 & 4721 & 4548 & 5294 & 6269 & 1637 & 29337 \\
\hline
\end{tabular}

Note: ${ }^{\dagger}$ denotes the sum of foreign analyst reports for industry $i$ in a given year. The percentage of the number of foreign analyst reports for a given industry to the total number of foreign analyst reports in a given year is displayed in parentheses. 
rate, hence the natural logarithm of total assets is used as a proxy variable for firm size. Return on assets is used as a proxy for profitability, measured by net income before extraordinary items divided by the average total assets. Leverage ratio is included to control for firms' financial distress, measured by total debt divided by total assets. Stock turnover rate is used to account for stock liquidity or investors' attention, defined as the total number of shares traded divided by total number of outstanding shares. Since institutional investors are the primary buyers of analyst reports, security house may gain underwriting revenues or commission fees from the provided reports (Firth et al. [6]). In addition, previous studies also find that institutional investors play an important role in the monitoring or governance of firms. For example, Aggarwal et al. [27] note that increasing foreign intuitional ownership for a firm can help to solidify the corporate governance mechanism. Hutchinson et al. [28] report that firm-specific risk, risk management policy, firm performance and institutional shareholdings are positively correlated. Bushee et al. [29] document that firms with higher instructional shareholding pay more attention to shareholder rights, which is an indispensable corporate governance mechanism for high growth firms. In conclusion, the institutional shareholding ratio is as a proxy variable for corporate governance, measured by shareholdings of mutual funds, pension funds, and other institutional investors divided by total number of outstanding shares. Also, since $70 \%$ of foreign analyst reports focus on electronic and biotechnological firms, the industry variable is not included in the empirical model. The definitions of variables are presented in Table 2.

\subsection{Econometric Method}

Most statistical methods assume that a sample of observations comes from the

Table 2. Variable definition.

\begin{tabular}{|c|c|c|}
\hline Variable & Symbol & Measurement \\
\hline Analyst reports & Report & $\begin{array}{l}\text { The number of foreign analyst reports for a firm in a } \\
\text { given year. }\end{array}$ \\
\hline Analyst coverage & Coverage & $\begin{array}{l}\text { Natural logarithm of the number of foreign analyst reports } \\
\text { for a firm in a given year. }\end{array}$ \\
\hline Price-to-book ratio & $P B$ & $\begin{array}{l}\text { Stock price per share divided by net assets per share at end } \\
\text { of fiscal year. }\end{array}$ \\
\hline Firm size & Size & Natural logarithm of total assets at the end of fiscal year. \\
\hline Return on assets & $R O A$ & $\begin{array}{l}\text { Net income before extraordinary items divided by } \\
\text { the average total assets at the end of fiscal year. }\end{array}$ \\
\hline Debt ratio & LeV & Total debt divided by total assets at the end of fiscal year. \\
\hline Stock turnover rate & Liq & $\begin{array}{l}\text { Total number of a stock traded divided by the total number of } \\
\text { outstanding shares for the stock at the end of fiscal year. }\end{array}$ \\
\hline Institutional ownership & Inst & $\begin{array}{l}\text { Shareholdings of mutual funds, pension funds, and other in- } \\
\text { stitutional investors divided by the total number of } \\
\text { outstanding shares at the end of fiscal year. }\end{array}$ \\
\hline
\end{tabular}

Note: this table defines main variables of interest. 
same distribution and make the restrictive hypothesis that the data distribution has a single mode, so they cannot properly detect heterogeneity in the sample. Previous studies have yet to jointly consider the issues of heterogeneity and clustering in data. The presence of heterogeneity, if not dealt with appropriately, could result in biased estimates as well (Caiazza et al. [30]). A finite mixture of distributions provides a flexible parametric framework for statistical modelling, allowing for unobserved heterogeneity in the population, by assuming that the population consists of $k$ homogeneous subgroups (Lubrano and Ndoye [31]). Finite mixture models also have the advantage of permitting cluster-specific regression functions, and thus, covariates have different effects in different clusters. This, in turn, results in means and variances that are also cluster-specific (Karlis et al. [32]). Consequently, finite mixture models are widely used in economic applications (Compiani and Kitamura [33]).

A finite mixture model is a convex combination of two or more probability density functions and uses a mixture of parametric distributions to model data, estimating both the parameters for the separate distributions and the probabilities of component membership for each observation. By combining the properties of the individual probability density functions, finite mixture models provide a flexible framework for analyzing a variety of data. Therefore, a finite mixture model provides a parametric alternative that describes the unknown distribution in terms of mixtures of known distributions and provides a mechanism that can account for unobserved heterogeneity in the data.

In a finite mixture model, $y$ is the vector of observed response variables assumed to come from $k$ distinct groups $f_{1}, f_{2}, \cdots, f_{k}$ in proportions $\pi_{1}, \pi_{2}, \cdots, \pi_{k}, x$ is the vector of independent variables, and $\beta_{j}$ is the vector of the coefficients for $y_{j}$. The expression of the density of likelihood of a response value $y$ in a general $k$-component mixture model is

$$
f(y)=\sum_{j=1}^{k} \pi_{j} f_{j}\left(y \mid x^{\prime} \beta_{j}\right)
$$

where $\pi_{j}$ is the probability for the $j$ th group, $0 \leq \pi_{j} \leq 1$ and $\sum \pi_{j}=1$, and $f_{j}($.$) is the conditional probability density function for the observed response$ in the $x$ th group model. The finite mixture models can be efficiently estimated via maximum likelihood and multinomial Logistic distribution is used to model the probabilities for the latent groups. The probability for the $j$ th latent group is given by

$$
\pi_{j}=\frac{\exp \left(\gamma_{j}\right)}{\sum_{j=1}^{k} \exp \left(\gamma_{j}\right)}
$$

where $\gamma_{j}$ is the linear prediction for the $j$ th latent group. The likelihood is computed as the sum of the probability-weighted conditional likelihood from each latent group.

Figure 1 depicts the distribution of pooled foreign analyst reports for the empirical data of this study. In Figure 1, histogram is the density distribution of 


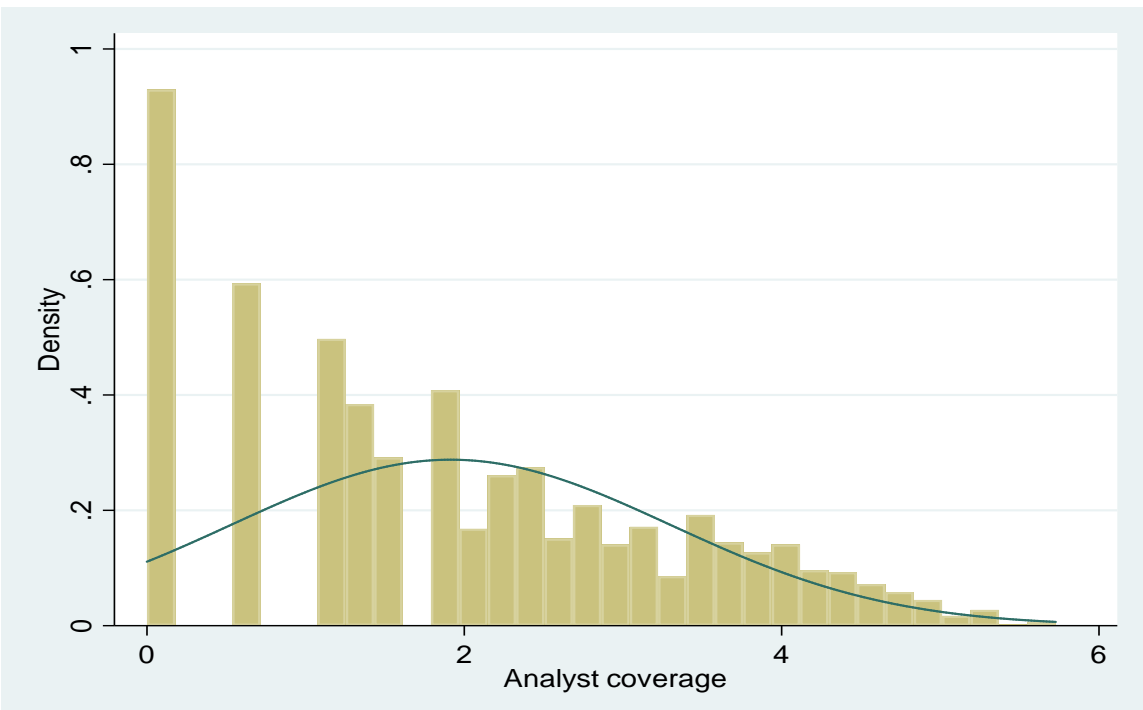

Figure 1. Distribution of foreign analyst coverage. Note: Data come from the Thomson Reuters's Eikon database.

pooled foreign analyst reports for empirical data of this study and the solid line is a theoretical normal distribution. The figure displays that the histogram does not follow a well-known distribution. The asymmetry occurs because the distribution could be a mixture of more than one subgroup. Models fit by using traditional techniques (single mode) can perform poorly, because they cannot necessarily tell which group a firm belongs to. A finite mixture model contains any number of subgroups and may be appropriate for these data. Therefore, a finite mixture model can be used to account for these unknown predictors and estimate the means and variances of the two or three underlying subgroups to make inferences about each subgroup and classify individual observations into different subgroups.

Because the foreign analyst reports are more than or equal to 0 , a Tobit regression finite mixture model is used for a sample of 366 firms listed on the Taiwan Stock Market. The model is as follows:

$$
\begin{aligned}
\text { Coverage }_{i j t}= & \alpha_{j}+\beta_{j 1} P B_{i j t-1}+\beta_{j 2} P B_{i j t-1}^{2}+\beta_{j 3} \text { Size }_{i j t-1}+\beta_{j 4} R O A_{i j t-1} \\
& +\beta_{j 5} L \operatorname{lev}_{i j t-1}+\beta_{j 6} L_{i j} q_{i j t-1}+\beta_{j 7} \text { Inst }_{i j t-1}+\varepsilon_{i j t}
\end{aligned}
$$

where Coverage ${ }_{i j t}$ is foreign analyst coverage measured by the natural logarithm of the number of analyst reports for the firm $i$ of the th subgroup in the year $t$. In order to avoid bias from endogeneity among variables, independent variables of Equation (3) are measured by a one-year lag. $P B_{i j t-1}$ is the price-to-book ratio measure by stock price per share divided by net assets per share for the firm $i$ of the $j$ th subgroup at the end of year $t-1 . P B_{i j t-1}^{2}$ is the square of $P B_{i j t-1}$ to depict the nonlinear correlation between price-to-book ratio and foreign analyst reports (Wang et al. [17]). Size ijt-1 $_{1}$ is the firm size defined as the natural logarithm of total assets for the firm $i$ of the th subgroup at the end of the year $t-1$. $R O A_{i j t-1}$ is return on assets and equals net income before extraordinary items di- 
vided by the average total assets for the firm $i$ of the th subgroup at the end of year $t-1 . \operatorname{LeV}_{i j t-1}$ is the leverage ratio and equals total liabilities divided by total assets for the firm $i$ of the $j$ th subgroup at the end of year $t-1 . L i q_{i j t-1}$ is the stock turnover rate calculated by the total number of shares traded divided by the total number of outstanding shares for the firm $i$ of the th subgroup at the end of year $t-1$. Inst $t_{j j t-1}$ is shareholdings of mutual funds, pension funds, and other institutional investors divided by the total number of outstanding shares for the firm $i$ of the $j$ th subgroup at the end of year $t-1 . j$ is the th subgroup, $j=1, \cdots, k . \varepsilon_{i j t}$ is an error term.

\section{Empirical Results}

\subsection{Descriptive Statistics}

Table 3 reports descriptive statistics and the correlation matrix of variables. Panel A reports the descriptive statistics of variables and shows a mean of 11.45 for the number of foreign analyst reports that a firm receives over the fiscal year. The minimum is 0 while the maximum is 307 , which reveals diverse foreign analyst following among firms. The firm characteristics, institutional ownership, and stock liquidity also vary greatly. Panel B represents the Spearman correlations of variables. In addition to firm size (measured by the natural logarithm of total assets) and ROA, the correlation coefficients are between -0.00935 and 0.4602 . The correlation between two variables could be classified into three categories: $|\rho| \leq 0.3$ is low linear correlation, $0.3<|\rho| \leq 0.7$ is a significant linear correlation, $|\rho|>0.7$ is a high linear correlation. In general, most variables show low linear correlation. Moreover, I also test the collinearity diagnostics among variables. The variance inflation factors (VIF) of variables are from 0.436 to 0.812 , and, as a whole, collinearities of variables are not obvious.

\subsection{Regression Results}

I use the Akaike information criterion (AIC) and Bayesian information criterion (BIC) for model selection, and pick the model with the smallest AIC and BIC. The AIC (BIC) for the single mode model, two-subgroup mixture model, and three-subgroup mixture model are 4806.669 (4855.231), 4609.428 (4711.946), 4604.903 (4761.379), respectively. The AIC clearly favors the three-subgroup mixture model, whereas the BIC marginally favors the two-subgroup mixture model. This study will proceed with the three-subgroup mixture model. Table 4 reports the results of the Tobit regression mixture model. Panel A reports the results of Tobit regression, the single-mode model assume that a sample of observations come from the same distribution and make the restrictive hypothesis that the data distribution has a single mode. The mixture model is a convex combination of two or more probability density functions and uses a mixture of parametric distributions to model data. The results of the single-mode model show that the estimated coefficients of all variables are significant. However, the mixture model indicates that estimated coefficients, statistical significance and 
Table 3. Descriptive statistics and correlation matrix.

Panel A. Descriptive statistics

\begin{tabular}{|c|c|c|c|c|c|c|c|c|}
\hline \multicolumn{2}{|c|}{ Variable } & \multicolumn{2}{|r|}{ Obs. } & Mean & \multicolumn{2}{|c|}{ Std. Dev. } & Min & Max \\
\hline \multicolumn{2}{|c|}{ Report } & \multicolumn{2}{|r|}{2.562} & 11.45 & \multicolumn{2}{|c|}{26.05} & 0 & 307 \\
\hline \multicolumn{2}{|c|}{$P B$} & \multicolumn{2}{|r|}{2.928} & 2.01 & \multicolumn{2}{|c|}{1.56} & 0.08 & 17.06 \\
\hline \multicolumn{2}{|c|}{$T A$ (ten billion) } & \multicolumn{2}{|r|}{2.928} & 4.51 & \multicolumn{2}{|c|}{10.88} & 0.03 & 191.64 \\
\hline \multicolumn{2}{|c|}{$R O A(\%)$} & \multicolumn{2}{|r|}{2.928} & 7.22 & \multicolumn{2}{|c|}{7.98} & -57.49 & 51.09 \\
\hline \multicolumn{2}{|c|}{$\operatorname{Lev}(\%)$} & \multicolumn{2}{|r|}{2.928} & 43.46 & \multicolumn{2}{|c|}{16.38} & 3.18 & 97.82 \\
\hline \multicolumn{2}{|c|}{ Liq } & \multicolumn{2}{|r|}{2.928} & 212.44 & \multicolumn{2}{|c|}{199.06} & 0.08 & 1581.28 \\
\hline \multicolumn{2}{|c|}{ Inst (\%) } & \multicolumn{2}{|r|}{2.928} & 45.15 & \multicolumn{2}{|c|}{22.29} & 0 & 97.96 \\
\hline \multicolumn{9}{|c|}{ Panel B. Correlation matrix } \\
\hline Variable & Coverage $_{t}$ & $P B_{t-1}$ & Size $_{t-1}$ & $R O A_{t-1}$ & $L e V_{t-1}$ & $\operatorname{Liq}_{t-1}$ & Inst $_{t-1}$ & VIF \\
\hline Coverage $_{t}$ & 1 & & & & & & & \\
\hline$P B_{t-1}$ & 0.2039 & 1 & & & & & & 0.590 \\
\hline Size $_{t-1}$ & 0.5493 & -0.1453 & 1 & & & & & 0.436 \\
\hline$R O A_{t-1}$ & 0.1492 & 0.5922 & -0.1921 & 1 & & & & 0.494 \\
\hline$L e v_{t-1}$ & 0.0261 & -0.1513 & 0.3516 & -0.3754 & 1 & & & 0.552 \\
\hline $\operatorname{Liq}_{t-1}$ & -0.0935 & 0.1986 & -0.2246 & 0.1036 & -0.0996 & 1 & & 0.812 \\
\hline Inst $_{t-1}$ & 0.4602 & 0.1648 & 0.505 & 0.1625 & 0.0786 & -0.2782 & 1 & 0.614 \\
\hline
\end{tabular}

Note: Report is the number of foreign analyst reports. Coverage is the foreign analyst coverage. $P B$ is the price-to-book ratio. TA is the total assets. Size is the firm size. LeV is the debt ratio. ROA is the return on assets. Liq is the stock turnover rate. Inst is the institutional ownership. The detailed definitions of variables are shown in Table 2. $t-1$ represents a one-year lag. VIF is the variance inflation factors.

correlation are different among the three subgroups. In addition, the joint coefficients testing $\left(\chi^{2}\right)$ for mixture model shows that price-to-book ratio, firm size, $\mathrm{ROA}$, and institutional ownership have significant differences among the three subgroups. Moreover, in general, foreign analyst coverage is significantly related with firm size and institutional ownership for the three subgroups. For subgroups 1 and 2, foreign analyst coverage and price-to-book ratio have an inverted U-shaped correlation (the coefficients of $P B$ and $P B^{2}$ for subgroup 1 are 0.6166 and -0.0234 , for subgroup 2 are 0.3969 and -0.0204 , respectively). Conversely, subgroup 3 has a $U$-shaped correlation, but it is insignificant. Additionally, firms' profitability, leverage and stock liquidity also affect foreign analyst coverage for subgroups 1 and 2. However, the determinants are firm size (the coefficient is 0.4976 ) and institutional ownership (the coefficient is 0.0262 ) for subgroup 3. In general, determinants of foreign analyst coverage are alike between subgroups 1 and 2 . The variances of Coverage $\left(\sigma_{\text {Coverage }}^{2}\right)$ in sequence are $1.9281,0.6383$, and 0.1048 . This illustrates that subgroup 1 has a higher variation in foreign analyst coverage.

After fitting the model, the marginal probability $(\pi)$ and mean $(\mu)$ for the $j$ th latent subgroup can be predicted for each of observation. Panel B reports the 
Table 4. Results of Tobit regression mixture model.

Panel A. Results of Tobit regression

\begin{tabular}{|c|c|c|c|c|c|}
\hline \multirow[b]{2}{*}{ Variable } & \multirow[b]{2}{*}{$\begin{array}{l}\text { Single-mode } \\
\text { model }\end{array}$} & \multicolumn{4}{|c|}{ Mixture Model } \\
\hline & & Subgroup 1 & Subgroup 2 & Subgroup 3 & $x^{2}$ \\
\hline$P B_{t-1}$ & $\begin{array}{c}0.4078^{* * *} \\
(0.044875)\end{array}$ & $\begin{array}{l}0.6166^{* * *} \\
(0.179503)\end{array}$ & $\begin{array}{l}0.3969^{* * *} \\
(0.087112)\end{array}$ & $\begin{array}{c}-0.0371 \\
(0.115536)\end{array}$ & $12.07^{* * *}$ \\
\hline$P B_{t-1}^{2}$ & $\begin{array}{l}-0.0201^{\star * *} \\
(0.002941)\end{array}$ & $\begin{array}{c}-0.0234^{* * *} \\
(0.008998)\end{array}$ & $\begin{array}{c}-0.0204^{* * *} \\
(0.005031)\end{array}$ & $\begin{array}{c}0.0033 \\
(0.005098)\end{array}$ & $11.65^{\star * *}$ \\
\hline Size $_{t-1}$ & $\begin{array}{l}0.6817^{\star * *} \\
(0.024701)\end{array}$ & $\begin{array}{l}1.2495^{\star * *} \\
(0.155162)\end{array}$ & $\begin{array}{l}0.6337^{* * *} \\
(0.04158)\end{array}$ & $\begin{array}{l}0.4976^{\star * *} \\
(0.092851)\end{array}$ & $21.89^{* * *}$ \\
\hline$R O A_{t-1}$ & $\begin{array}{l}0.0208^{* * *} \\
(0.005819)\end{array}$ & $\begin{array}{l}0.0624^{* * *} \\
(0.020724)\end{array}$ & $\begin{array}{l}0.0173^{* *} \\
(0.00847)\end{array}$ & $\begin{array}{c}0.0075 \\
(0.016081)\end{array}$ & $5.10^{*}$ \\
\hline $\operatorname{Lev}_{t-1}$ & $\begin{array}{l}-0.0097^{* * *} \\
(0.002266)\end{array}$ & $\begin{array}{l}-0.0195^{\star} \\
(0.010801)\end{array}$ & $\begin{array}{l}-0.0098^{\star *} \\
(0.004974)\end{array}$ & $\begin{array}{c}0.0001 \\
(0.013132)\end{array}$ & 1.59 \\
\hline $\operatorname{Liq}_{t-1}$ & $\begin{array}{l}0.0011^{\star * *} \\
(0.000167)\end{array}$ & $\begin{array}{l}0.0021^{* * *} \\
(0.000763)\end{array}$ & $\begin{array}{l}0.0007^{* * *} \\
(0.0002)\end{array}$ & $\begin{array}{c}0.0017 \\
(0.001925)\end{array}$ & 2.82 \\
\hline Inst $_{t-1}$ & $\begin{array}{l}0.0112^{\star * \star} \\
(0.001679)\end{array}$ & $\begin{array}{c}0.0151^{*} \\
(0.008788)\end{array}$ & $\begin{array}{c}0.0088^{* * *} \\
(0.0019)\end{array}$ & $\begin{array}{l}0.0262^{* * *} \\
(0.00602)\end{array}$ & $8.45^{\star *}$ \\
\hline Constant & $\begin{array}{l}-0.0264^{* * *} \\
(0.151389)\end{array}$ & $\begin{array}{l}-3.4453^{* * *} \\
(0.780163)\end{array}$ & $\begin{array}{l}0.5726^{* * *} \\
(0.189547)\end{array}$ & $\begin{array}{c}0.7762^{* *} \\
(0.371734)\end{array}$ & $28.55^{* * *}$ \\
\hline$\sigma_{\text {Coverage }}^{2}$ & $\begin{array}{c}1.3183 \\
(0.056565)\end{array}$ & $\begin{array}{c}1.9281 \\
(0.389146)\end{array}$ & $\begin{array}{c}0.6383 \\
(0.062649)\end{array}$ & $\begin{array}{c}0.1048 \\
(0.13626)\end{array}$ & \\
\hline $\begin{array}{l}\text { log pseudo } \\
\text { likelihood }\end{array}$ & -2394.3347 & & & & \\
\hline Pseudo $\mathrm{R}^{2}$ & 0.1692 & & & & \\
\hline $\mathrm{F}$ & $224.26^{* * *}$ & & & & \\
\hline AIC & 4806.669 & & 4604.903 & & \\
\hline $\mathrm{BIC}$ & 4855.231 & & 4761.379 & & \\
\hline
\end{tabular}

Panel B. Predictive probabilities and means for three subgroups

\begin{tabular}{cccc}
\hline \multirow{2}{*}{ Variable } & \multicolumn{3}{c}{ Mixture Model } \\
\cline { 2 - 4 } & Subgroup 1 & Subgroup 2 & Subgroup 3 \\
\cline { 2 - 4 }$\pi$ & 0.218268 & 0.684212 & 0.09752 \\
& $(0.038933)^{\dagger}$ & $(0.038933)$ & $(0.066442)$ \\
$\mu$ & -0.3487522 & $2.114604^{* * *}$ & $2.870259^{* * *}$ \\
& $(0.4287458)^{\dagger}$ & $(0.0893956)$ & $(0.1371312)$ \\
\hline
\end{tabular}

Note: The dependent variable is the Coverage. $P B$ is the price-to-book ratio. Size is the firm size. Lev is the debt ratio. $R O A$ is the return on assets. $L i q$ is the stock turnover rate. Inst is the institutional ownership. $t-$ 1 represents a one-year lag. The detailed definitions of variables are shown in Table 2. Robust standard errors are displayed in parentheses. $\chi^{2}$ is the joint test of estimated coefficients for three subgroups. $\sigma_{\text {Coverage }}$ is the variance of Coverage. $\pi$ and $\mu$ is the marginal probability and mean for the $t$ th latent subgroup. ${ }^{\dagger}$ denotes the delta-method standard error. Asterisks ${ }^{* *},{ }^{* *},{ }^{*}$ indicate significant levels of $1 \%, 5 \%$, and $10 \%$, respectively.

predictive probabilities and means for three subgroups and shows that about $21.83 \%$ of observations are in subgroup 1 , about $68.42 \%$ are in subgroup 2 , and about $9.75 \%$ are in subgroup 3 . The subgroups 2 and 3 correspond to more foreign analyst coverage, with average analyst coverage of 2.11 and 2.87 , respectively. As a whole, the foreign analysts are in favor of subgroup 3, and determinants affecting foreign analyst following are firm size and institutional ownership.

In conclusion, the determinants of foreign analyst coverage have substantial 
differences among the three subgroups. The results of the mixture model show that coefficients of independent variables for the three subgroups are significantly different from one another, with the exceptions of financial leverage and stock turnover rate. Using a single-mode model can explain the average effect for whole sample, but a mixture model can interpret the heterogeneous effects in different subgroups.

I further depict the scatter matrixes for foreign analyst reports, price-to-book ratio, total assets, stock turnover rate and institutional ownership. Figure 2 displays that the correlation between foreign analyst reports and price-to-book ratio is nonlinear, and that foreign analyst reports are positively related to institutional ownership, but negatively related to stock turnover rate. Moreover, firm size, institutional ownership, and stock turnover rate are correlation for each other. Thus, a nonlinear correlation exists between institutional ownership and stock turnover rate.

For further analysis, the price-to-book ratio, firm size (measured by total assets), stock turnover rate and institutional ownership of whole sample are arranged in descending order in a given year and classified into three distinct categories based on a bottom 30\%, middle $40 \%$ and top 30\% criteria (labeled as small or low, medium, and large or high categories). Next, each firm belongs to one of the three categories, varying for any given year.

Figure 3 depicts scatter diagrams of the number of foreign analyst reports by price-to-book ratio, firm size, stock turnover rate, and institutional ownership. Figures 3(a)-(d) show that a firm with high price-to-book ratio, large firm size,

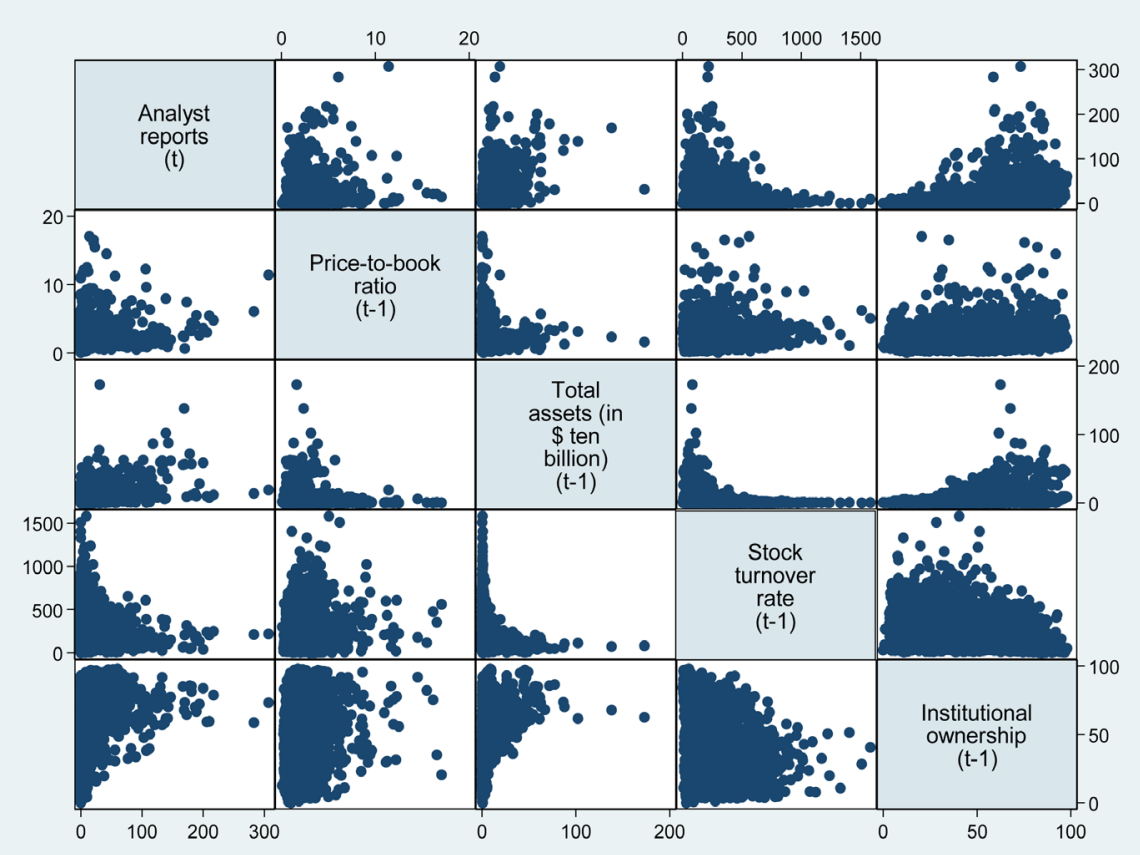

Figure 2. Scatter matrixes for foreign analyst reports, price-to-book ratio, total assets, stock turnover rate and institutional ownership. Note: Data come from the Thomson Reuters's Eikon database and Taiwan Economic Journal Company (TEJ). 


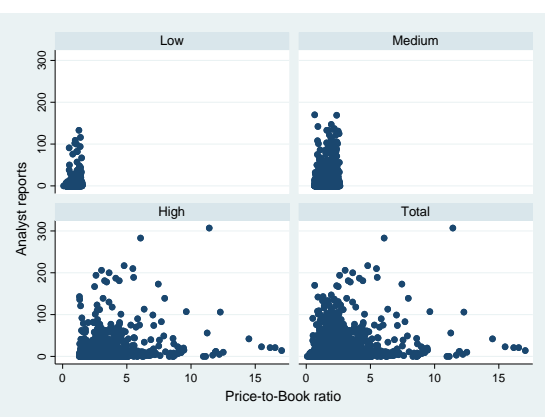

(a)

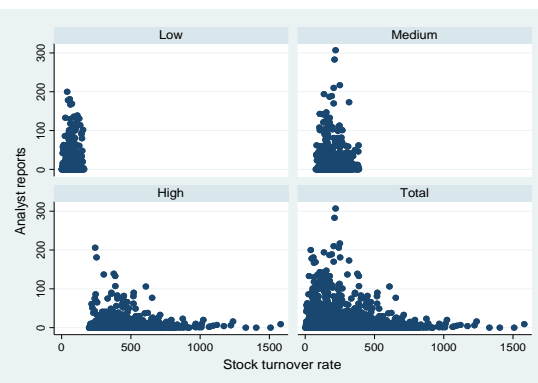

(c)

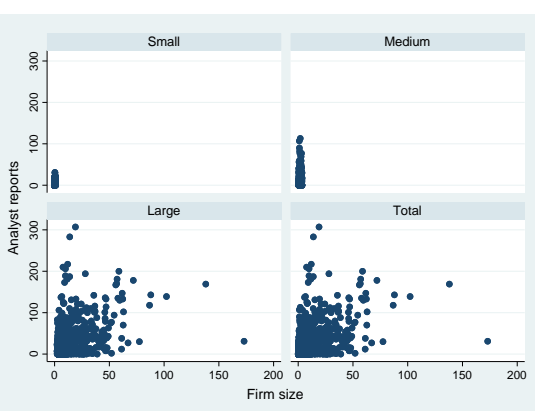

(b)

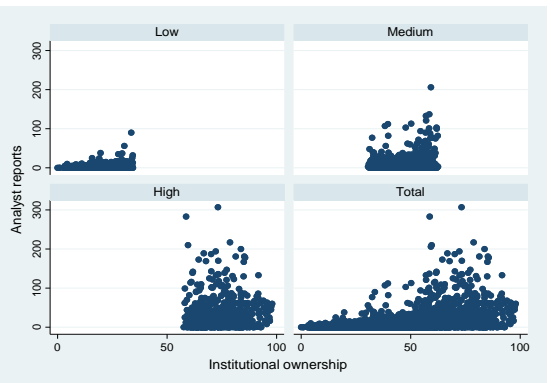

(d)

Figure 3. Scatter diagrams of foreign analyst reports by price-to-book rate, firm size, stock turnover rate, and institutional ownership. (a) Price-to-book ratio; (b) Firm size; (c) Stock turnover rate; (d) Institutional ownership. Note: Data come from the Thomson Reuters's Eikon database and Taiwan Economic Journal Company (TEJ).

and high institutional ownership attracts significantly more analyst following. Figure 3(c) shows that the number of foreign analyst reports decreasing along with rising stock turnover rate for a firm with a high stock turnover rate.

Figure 4 plots the foreign analyst reports across different firm sizes, institutional ownership, and stock turnover rates. As a whole, firm size is a major concern for foreign analyst. For small-sized and medium-sized firms, foreign analyst coverage increases as institutional ownership and stock turnover rate rise. For large-sized firms, foreign analyst coverage increases as institutional ownership rises, and foreign analysts favor a firm with either a low or medium stock turnover rate.

In short, aforementioned results indicate that price-to-book ratio, firm size, stock turnover rate, and institutional ownership are the important characteristics affecting foreign analyst coverage. Further, I detect the different influence effects on foreign analyst coverage from these characteristics. First, the number of foreign analyst reports of whole sample is arranged in descending order in a given year. Thus, the samples are divided into two classes (i.e. high foreign analyst coverage and low foreign analyst coverage) based on the 70th percentile, varying for any given year. And also, the price-to-book ratio, firm size (measured by total assets), stock turnover rate and institutional ownership of whole sample are arranged in descending order in a given year, and they are also classified into three distinct categories based on a bottom $30 \%$, middle $40 \%$ and top $30 \%$ 


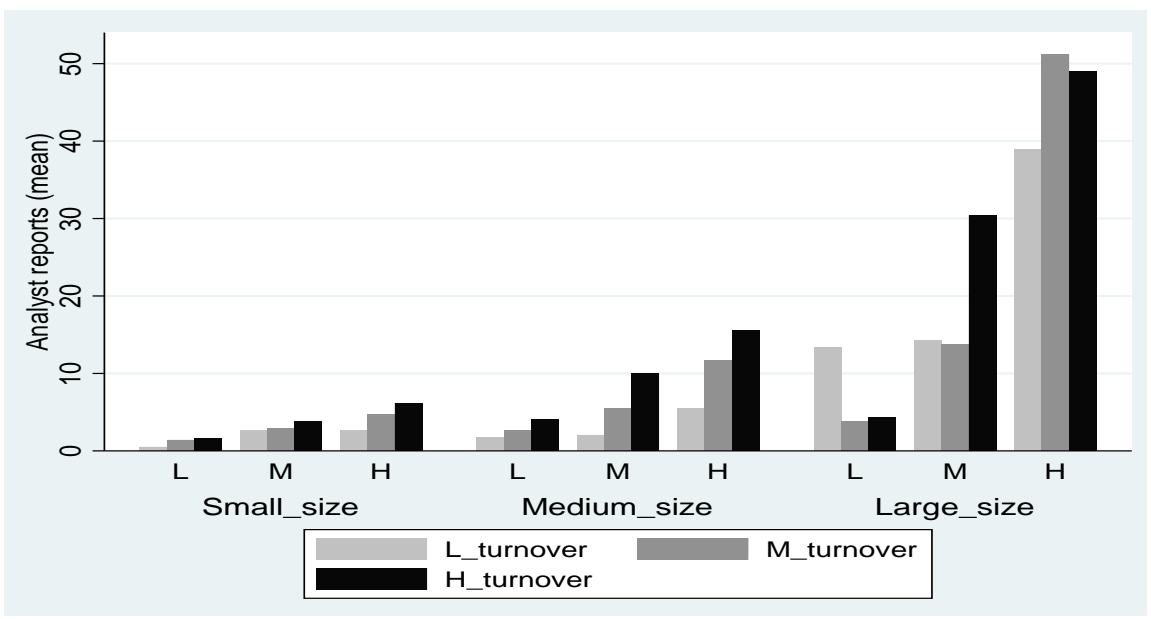

Figure 4. Foreign analyst reports for different firm size, stock turnover rate and institutional ownership. Note: Data come from the Thomson Reuters's Eikon database and Taiwan Economic Journal Company (TEJ). Notations L, M, H represent the three categories of institutional ownership.

criteria (labeled as small or low, medium, and large or high categories). Each firm belongs to one of the three categories, varying for any given year.

Next, a Logistic regression model is used to investigate the influence of the categories of price-to-book ratio, firm size, stock turnover rate and institutional ownership on foreign analyst coverage, and estimate the marginal effects for categorical variables. The computation of marginal effect for level $k$ of categorical variable $F$ is $h(z, \theta)=f(z, \theta \mid A=$ base $)$, where $\theta$ is a vector of parameters in the model fit, and $z$ is a vector of covariate values. The model specification is as follows:

$$
\begin{aligned}
\text { Highcover }_{i t}= & \alpha_{0}+\beta_{1} \text { ROA }_{i t-1}+\beta_{2} \text { Lev }_{i t-1}+\sum_{k=1}^{3} \varphi_{k} \text { PBclass }_{i t-1} \\
& +\sum_{k=1}^{3} \gamma_{k} \text { Sizeclass }_{i t-1}+\sum_{k=1}^{3} \tau_{k} \text { Liqclass }_{i t-1} \\
& +\sum_{k=1}^{3} \delta_{k} \text { Instclass }_{i t-1}+\varepsilon_{i t}
\end{aligned}
$$

where Highcover is an indicator variable, Highcover equals 1 if the number of foreign analyst reports for a firm is greater than the 70th percentile, and 0 otherwise. PBclass, Sizeclass, Liqclass and Instclass are all categorical variables. The firm size (measured by total assets), stock turnover rate and institutional ownership of whole sample are arranged in descending order in a given year, and they are also classified into three distinct categories based on a bottom $30 \%$, middle $40 \%$ and top $30 \%$ criteria (small or low is labeled as the category " 1 ", medium is labeled as the category " 2 ", and large or high is labeled as the category " 3 "). Each firm belongs to one of the three categories, varying for any given year. $R O A$ and $L e v$ are continuous variables, and those definitions are the same as in Equation (3). $\varepsilon_{i t}$ is an error term.

Table 5 reports the results of Logistic regression and probabilities for category variables. Panel A reports the results of Logistic regression and the constant estimates are baseline odds. The results indicate that firms with high price-to-book 
Table 5. Results of Logistic regression and probabilities for category variables.

Panel A. Result of Logistic regression

\begin{tabular}{|c|c|c|c|c|}
\hline Variable & Odds ratio & Robust Std. Err. & \multicolumn{2}{|c|}{ [95\% Conf. Interval] } \\
\hline \multicolumn{5}{|l|}{ PBclass $_{t-1}$} \\
\hline 2 & $4.129085^{* * *}$ & 0.7382869 & 2.908423 & 5.862056 \\
\hline 3 & $9.383735^{* * *}$ & 1.971884 & 6.215921 & 14.16596 \\
\hline \multicolumn{5}{|l|}{ Sizeclass $_{t-1}$} \\
\hline 2 & $5.475737^{\star}$ & 4.84959 & 0.9651069 & 31.06775 \\
\hline 3 & $55.76454^{* * *}$ & 49.18422 & 9.899198 & 314.135 \\
\hline \multicolumn{5}{|l|}{ Liqclass $_{t-1}$} \\
\hline 2 & 0.6970638 & 0.5508359 & 0.1481268 & 3.280285 \\
\hline 3 & 1.772752 & 1.167591 & 0.4875504 & 6.445792 \\
\hline \multicolumn{5}{|l|}{ Instclass $_{t-1}$} \\
\hline 2 & 2.592656 & 1.836844 & 0.6466749 & 10.3945 \\
\hline 3 & 2.759402 & 2.271615 & 0.5496452 & 13.85311 \\
\hline \multicolumn{5}{|c|}{ Sizeclass $_{t-1} \times$ Liqcalss $_{t-1} \times$ Instclass $_{t-1}$} \\
\hline $1 \times 2 \times 2$ & 1.097017 & 1.015292 & 0.1788236 & 6.7298 \\
\hline $1 \times 2 \times 3$ & 2.444862 & 2.702787 & 0.2800619 & 21.34297 \\
\hline $1 \times 3 \times 2$ & 0.7712119 & 0.6295108 & 0.1557293 & 3.819241 \\
\hline $1 \times 3 \times 3$ & 1.131952 & 1.153567 & 0.1535933 & 8.342258 \\
\hline $2 \times 1 \times 2$ & 0.5786175 & 0.593108 & 0.077602 & 4.314297 \\
\hline $2 \times 1 \times 3$ & 0.5519772 & 0.5986246 & 0.0658847 & 4.624421 \\
\hline $2 \times 2 \times 1$ & 1.276969 & 1.403108 & 0.1482169 & 11.00179 \\
\hline $2 \times 2 \times 2$ & 1.289152 & 1.957474 & 0.065739 & 25.28048 \\
\hline $2 \times 2 \times 3$ & 2.504195 & 3.952845 & 0.1135156 & 55.24343 \\
\hline $2 \times 3 \times 1$ & 0.7787215 & 0.7498958 & 0.1179476 & 5.141324 \\
\hline $2 \times 3 \times 2$ & 1.05153 & 1.523961 & 0.0614034 & 18.00739 \\
\hline $2 \times 3 \times 3$ & 1.650883 & 2.51852 & 0.0830152 & 32.83032 \\
\hline $3 \times 1 \times 2$ & 0.8067293 & 0.7971702 & 0.1163087 & 5.595557 \\
\hline $3 \times 1 \times 3$ & 1.67187 & 1.769251 & 0.2100976 & 13.30405 \\
\hline $3 \times 2 \times 1$ & 1.470303 & 1.615996 & 0.1705531 & 12.67518 \\
\hline $3 \times 2 \times 2$ & 0.7714073 & 1.168408 & 0.0396292 & 15.01593 \\
\hline $3 \times 2 \times 3$ & 3.374853 & 5.328192 & 0.1528918 & 74.49473 \\
\hline $3 \times 3 \times 1$ & 0.4056751 & 0.4531118 & 0.0454406 & 3.621706 \\
\hline $3 \times 3 \times 2$ & 0.3975546 & 0.5841303 & 0.0223213 & 7.080668 \\
\hline $3 \times 3 \times 3$ & 0.7159015 & 1.133447 & 0.0321509 & 15.94092 \\
\hline$R O A_{t-1}$ & $1.045951^{* * *}$ & 0.0108662 & 1.024869 & 1.067466 \\
\hline$L e V_{t-1}$ & $0.9776074^{* * *}$ & 0.0040476 & 0.9697064 & 0.9855728 \\
\hline Constant & $0.0085502^{* * *}$ & 0.005327 & 0.0025215 & 0.028993 \\
\hline Log pseudolikelihood & -962.42376 & & & \\
\hline Pseudo $\mathrm{R}^{2}$ & 0.3589 & & & \\
\hline Wald $\chi^{2}$ & $624.75^{* * *}$ & & & \\
\hline
\end{tabular}


Panel B. Probability for category variables

\begin{tabular}{|c|c|c|c|c|}
\hline Category variable & $\begin{array}{c}\text { Predicted } \\
\text { probabilities }\end{array}$ & $\begin{array}{l}\text { Delta-method } \\
\text { Std. Err. }\end{array}$ & \multicolumn{2}{|c|}{ [95\% Conf. Interval] } \\
\hline \multicolumn{5}{|l|}{ PBclass $_{t-1}$} \\
\hline 1 & $0.1355545^{\star * *}$ & 0.0123824 & 0.1112854 & 0.1598236 \\
\hline 2 & $0.2840843^{* * *}$ & 0.0112606 & 0.2620139 & 0.3061547 \\
\hline 3 & $0.3976174^{\star * *}$ & 0.0165076 & 0.3652631 & 0.4299716 \\
\hline \multicolumn{5}{|l|}{ Sizeclass $_{t-1}$} \\
\hline 1 & $0.0711809^{* * *}$ & 0.0094132 & 0.0527314 & 0.0896305 \\
\hline 2 & $0.2328578^{* * *}$ & 0.0119475 & 0.2094412 & 0.2562744 \\
\hline 3 & $0.5879989^{* * *}$ & 0.02451 & 0.5399602 & 0.6360375 \\
\hline \multicolumn{5}{|l|}{ Liqclass $_{t-1}$} \\
\hline 1 & $0.2396476^{\star * *}$ & 0.0133295 & 0.2135223 & 0.265773 \\
\hline 2 & $0.2668302^{\star * *}$ & 0.010664 & 0.2459291 & 0.2877312 \\
\hline 3 & $0.3084775^{\star * *}$ & 0.0168676 & 0.2754177 & 0.3415373 \\
\hline \multicolumn{5}{|l|}{ Instclass $_{t-1}$} \\
\hline 1 & $0.1696897^{\star * *}$ & 0.0188182 & 0.1328067 & 0.2065727 \\
\hline 2 & $0.2660432^{* * *}$ & 0.0115586 & 0.2433886 & 0.2886977 \\
\hline 3 & $0.368912^{\star * *}$ & 0.0184931 & 0.3326661 & 0.4051578 \\
\hline \multicolumn{5}{|c|}{ Sizeclass $_{t-1} \times$ Liqcalss $_{t-1} \times$ Instclass $_{t-1}$} \\
\hline $1 \times 1 \times 1$ & $0.0304525^{*}$ & 0.0168657 & -0.0026037 & 0.0635088 \\
\hline $1 \times 1 \times 2$ & $0.070881^{* * *}$ & 0.0227097 & 0.0263709 & 0.1153911 \\
\hline $1 \times 1 \times 3$ & $0.0746917^{\star *}$ & 0.0353158 & 0.0054741 & 0.1439093 \\
\hline $1 \times 2 \times 1$ & $0.0217427^{\star *}$ & 0.0105768 & 0.0010126 & 0.0424729 \\
\hline $1 \times 2 \times 2$ & $0.0563202^{\star * *}$ & 0.0149242 & 0.0270693 & 0.085571 \\
\hline $1 \times 2 \times 3$ & $0.114758^{\star *}$ & 0.0473957 & 0.0218641 & 0.2076519 \\
\hline $1 \times 3 \times 1$ & $0.0510669^{* * *}$ & 0.0124903 & 0.0265864 & 0.0755474 \\
\hline $1 \times 3 \times 2$ & $0.0917777^{\star * *}$ & 0.0220358 & 0.0485883 & 0.1349671 \\
\hline $1 \times 3 \times 3$ & $0.129955^{\star *}$ & 0.0523405 & 0.0273694 & 0.2325405 \\
\hline $2 \times 1 \times 1$ & $0.1288703^{\star *}$ & 0.0629395 & 0.0055112 & 0.2522294 \\
\hline $2 \times 1 \times 2$ & $0.1727538^{\star * *}$ & 0.0422293 & 0.0899859 & 0.2555217 \\
\hline $2 \times 1 \times 3$ & $0.1745787^{\star * *}$ & 0.0333494 & 0.1092152 & 0.2399423 \\
\hline $2 \times 2 \times 1$ & $0.1179662^{\star * *}$ & 0.0368469 & 0.0457475 & 0.1901848 \\
\hline $2 \times 2 \times 2$ & $0.2308493^{* * *}$ & 0.0286485 & 0.1746992 & 0.2869994 \\
\hline $2 \times 2 \times 3$ & $0.347857^{* * *}$ & 0.0404086 & 0.2686577 & 0.4270564 \\
\hline $2 \times 3 \times 1$ & $0.1630014^{\star * *}$ & 0.0303205 & 0.1035744 & 0.2224284 \\
\hline $2 \times 3 \times 2$ & $0.3484473^{* * *}$ & 0.0297915 & 0.2900571 & 0.4068376 \\
\hline $2 \times 3 \times 3$ & $0.4419518^{\star * *}$ & 0.0539001 & 0.3363096 & 0.547594 \\
\hline $3 \times 1 \times 1$ & $0.4854079^{* * *}$ & 0.1201868 & 0.2498461 & 0.7209697 \\
\hline
\end{tabular}


Continued

\begin{tabular}{lllll}
\hline $3 \times 1 \times 2$ & $0.6210869^{* * *}$ & 0.0461412 & 0.5306519 & 0.7115219 \\
$3 \times 1 \times 3$ & $0.749726^{* * *}$ & 0.0274375 & 0.6959495 & 0.8035024 \\
$3 \times 2 \times 1$ & $0.4900233^{* * *}$ & 0.0783641 & 0.3364325 & 0.6436142 \\
$3 \times 2 \times 2$ & $0.5474978^{* * *}$ & 0.0392161 & 0.4706357 & 0.6243599 \\
$3 \times 2 \times 3$ & $0.7968666^{* * *}$ & 0.0334876 & 0.7312321 & 0.862501 \\
$3 \times 3 \times 1$ & $0.4237726^{* * *}$ & 0.1186025 & 0.191316 & 0.6562292 \\
$3 \times 3 \times 2$ & $0.596981^{* * *}$ & 0.0564475 & 0.486346 & 0.707616 \\
$3 \times 3 \times 3$ & $0.7077108^{* * *}$ & 0.0834942 & 0.5440653 & 0.8713564 \\
\hline
\end{tabular}

Note: The dependent variable is Highcover, an indicator variable. PBclass, Sizeclass, Liqclass and Instclass are all categorical variables, small or low is labeled as the category " 1 ", medium is labeled as the category " 2 ", and large or high is labeled as the category " 3 ". Lev is the debt ratio. $R O A$ is the return on assets. $t-1$ represents a one-year lag. Asterisks ${ }^{* * *},{ }^{* *},{ }^{*}$ indicate significant levels of $1 \%, 5 \%$, and $10 \%$, respectively.

ratio or large firm size are 9 times and 55 times more likely to be frequently followed by foreign analysts than firms with low price-to-book ratio or small firm size, respectively. Moreover, Panel B reports the probabilities of category variables and reveals that the likelihoods for firms with high price-to-book ratio, large firm size, high stock turnover rate, high institutional ownership to be frequently followed by foreign analysts are $39.76 \%, 58.80 \%, 30.85 \%$, and $36.89 \%$, respectively, which are significantly higher than those for the other types of firms. This means that foreign analysts prefer firms with the aforementioned characteristics. From the combinations of the three variables-firm size, stock turnover rate, and institutional ownership, I further find that the higher institutional ownership is, the more likely it is for the firm to be followed by foreign analysts. And further, in small-sized or medium-sized firms that have high stock turnover rate and high institutional ownership, the mean of probabilities to be frequently followed are $13 \%$ and $44 \%$, respectively. The probability for firms with large firm size, medium stock turnover rate and high institutional ownership to be frequently followed by foreign analysts is $79.69 \%$, which is the highest among the 18 combinations. In conclusion, the results of Logistic regression suggest that price-to-book ratio, firm size, and institutional ownership are the three key variables of foreign analyst coverage.

\section{Robustness Tests}

In the Taiwan Stock Market, foreign institutional investors, domestic trust institutional investors, and domestic dealer institutional investors are called the three institutional investors. Table 6 displays the summary statistics of ownership of three institutional investors. The definitions of ownership of three institutional investors are as follows: the percentage of foreign institutional ownership (Foreignholding) equals ownership held by foreign institutional investors divided by the total number of outstanding shares at the end of year; the percentage of domestic investment trust institutional ownership (Trustholding) equals ownership held by domestic investment trust institutional investors divided by 
Table 6. Descriptive statistics for three institutional investors.

\begin{tabular}{cccccc}
\hline Variable & Obs. & Mean & Std. Dev. & Min & Max \\
\hline Foreignholding (\%) & 2.920 & 14.65 & 15.29 & 0 & 78.29 \\
Trusttholding (\%) & 2.920 & 2.59 & 3.97 & 0 & 30.71 \\
Dealerholding (\%) & 2.920 & 0.18 & 0.54 & 0 & 8.24 \\
\hline
\end{tabular}

Note: Foreignholding is the foreign institutional ownership, Trustholding is the domestic investment trust institutional ownership, Dealerholding is the domestic dealer institutional ownership.

the total number of outstanding shares at the end of year; the percentage of domestic dealer institutional ownership (Dealerholding) equals ownership held by domestic dealer institutional investors divided by the total number of outstanding shares at the end of year. In Table 6, the means of percentage of ownership for foreign institutional investors, domestic investment trust institutional investors, and domestic dealer institutional investors are $14.65 \%, 2.59 \%, 0.18 \%$, respectively. This shows that foreign institutional investors play an important role in the Taiwan Stock Market. In addition, the minimum and maximum values show that the ownership of three institutional investors is variable.

Wang et al. [17] find that foreign analyst coverage has a close positive correlation with foreign institutional ownership. In Table 4, the prior probability of being in a given subgroup is assumed to be the same for each individual, but this assumption that the probabilities of belonging to particular subgroup are the same for all individuals does not seem realistic for the data. It seems more reasonable to think that individual characteristics predict the probability of being in a given group conditional on foreign institutional shareholding. Hence, the latent subgroup probabilities are modeled conditional on foreign institutional ownership in the last year a firm had to perform the following additional checks. The results are presented in Table 7.

Panel A reports the results of Tobit regression mixture model and indicates that price-to-book ratio, firm size, and foreign institutional ownership are the important determinants of foreign analyst coverage for the three subgroups. For subgroups 1 and 3, foreign analyst coverage and price-to-book ratio have a significantly inverted U-shaped correlation. In contrast, subgroup 2 has a significant $\mathrm{U}$-shaped correlation. Additionally, both stock turnover rate and domestic trust institutional ownership affect foreign analyst coverage for subgroups 2 and 3. However, stock turnover rate and foreign institutional ownership have a negative correlation with foreign analyst coverage for subgroup 3 . The joint coefficients testing $\left(\chi^{2}\right)$ reveals that estimated coefficients have significant differences for the three subgroups, with the exceptions of profitability (measured by ROA) and domestic dealer institutional ownership. Moreover, subgroups 1 and 3 have higher heterogeneous (variances of Coverage are 0.5776 and 0.5845 , respectively) than subgroup 2. Panel B reports the predictive probabilities and means for three subgroups and shows that about $76.49 \%$ of observations are in subgroup 3 , which also corresponds to more foreign analyst coverage (the mean is 2.20). These 
Table 7. Results of Tobit regression mixture model conditional on foreign institutional ownership.

Panel A. Results of Tobit regression

\begin{tabular}{|c|c|c|c|c|}
\hline \multirow[b]{2}{*}{ Variable } & \multicolumn{3}{|c|}{ Mixture Model } & \multirow[b]{2}{*}{$\chi^{2}$} \\
\hline & Subgroup 1 & Subgroup 2 & Subgroup 3 & \\
\hline$P B_{t-1}$ & $\begin{array}{c}0.5616^{* *} \\
(0.2398129)\end{array}$ & $\begin{array}{l}-0.1107^{\star * *} \\
(0.0388567)\end{array}$ & $\begin{array}{c}0.2226^{* * *} \\
(0.0428114)\end{array}$ & $27.81^{\star * *}$ \\
\hline$P B_{t-1}^{2}$ & $\begin{array}{c}-0.0284^{*} \\
(0.0146391)\end{array}$ & $\begin{array}{c}0.3521^{* * *} \\
(0.0033125)\end{array}$ & $\begin{array}{l}-0.0096^{* * *} \\
(0.002591)\end{array}$ & $106.94^{* * *}$ \\
\hline Size $_{t-1}$ & $\begin{array}{c}1.2044^{\star * *} \\
(0.2708114)\end{array}$ & $\begin{array}{c}1.2611^{\star * *} \\
(0.0765631)\end{array}$ & $\begin{array}{c}0.5406^{* * *} \\
(0.0263044)\end{array}$ & $89.91^{\star * *}$ \\
\hline$R O A_{t-1}$ & $\begin{array}{c}0.0912 \\
(0.0759125)\end{array}$ & $\begin{array}{c}0.0007 \\
(0.0098878)\end{array}$ & $\begin{array}{c}0.0061 \\
(0.0047716)\end{array}$ & 1.27 \\
\hline $\operatorname{LeV}_{t-1}$ & $\begin{array}{c}0.0130 \\
(0.0559906)\end{array}$ & $\begin{array}{l}-0.0384^{* * *} \\
(0.0045376)\end{array}$ & $\begin{array}{l}-0.0095^{* * *} \\
(0.0025689)\end{array}$ & $45.59^{* * *}$ \\
\hline$L i q_{t-1}$ & $\begin{array}{c}0.0034 \\
(0.0037788)\end{array}$ & $\begin{array}{l}-0.0044^{* * *} \\
(0.0003048)\end{array}$ & $\begin{array}{c}0.0003^{* *} \\
(0.0001746)\end{array}$ & $211.81^{\star * *}$ \\
\hline Foreignholding $_{t-1}$ & $\begin{array}{c}0.0247^{\star} \\
(0.0130906)\end{array}$ & $\begin{array}{l}-0.0490^{\star * *} \\
(0.0036719)\end{array}$ & $\begin{array}{c}0.0211^{\star * *} \\
(0.0018234)\end{array}$ & $309.32^{* * *}$ \\
\hline Trustholding ${ }_{t-1}$ & $\begin{array}{c}0.0637 \\
(0.049107)\end{array}$ & $\begin{array}{c}0.2495^{* * *} \\
(0.0156875)\end{array}$ & $\begin{array}{c}0.0432^{\star \star \star} \\
(0.0069614)\end{array}$ & $144.60^{* * *}$ \\
\hline Dealerhold $_{t-1}$ & $\begin{array}{c}0.1388 \\
(0.1879989)\end{array}$ & $\begin{array}{c}0.0418 \\
(0.0267994)\end{array}$ & $\begin{array}{c}0.0291 \\
(0.0515551)\end{array}$ & 0.31 \\
\hline Constant & $\begin{array}{c}-4.2035 \\
(4.554452)\end{array}$ & $\begin{array}{c}0.1869 \\
(0.3103334)\end{array}$ & $\begin{array}{c}1.1317^{\star * \star} \\
(0.1299916)\end{array}$ & $18.25^{\star * *}$ \\
\hline$\sigma_{\text {Coverage }}^{2}$ & $\begin{array}{c}0.5776 \\
(0.6578761)\end{array}$ & $\begin{array}{c}0.0058 \\
(0.0032637)\end{array}$ & $\begin{array}{c}0.5845 \\
(0.0915142)\end{array}$ & \\
\hline Log pseudolikelihood & -2170.2853 & & & \\
\hline AIC & 4414.571 & & & \\
\hline BIC & 4617.053 & & & \\
\hline
\end{tabular}

Panel B. Predictive probabilities and means for three subgroups

\begin{tabular}{cccc}
\hline \multirow{2}{*}{ Variable } & \multicolumn{3}{c}{ Mixture Model } \\
\cline { 2 - 4 } & Subgroup 1 & Subgroup 2 & Subgroup 3 \\
\hline \multirow{2}{*}{$\pi$} & 0.1409299 & 0.0941373 & 0.7649328 \\
& $(0.112335)^{\dagger}$ & $(0.031392)$ & $(0.084975)$ \\
$\mu$ & $0.6269242^{* *}$ & $-1.774228^{* * *}$ & $2.205695^{\star * *}$ \\
& $(0.2757)^{\dagger}$ & $(0.1104703)$ & $(0.1101334)$ \\
\hline
\end{tabular}

Note: The dependent variable is Coverage. $P B$ is the price-to-book ratio. Size is the firm size. Lev is the debt ratio. $R O A$ is the return on assets. $L i q$ is the stock turnover rate. The detailed definitions of variables are shown in Table 2. Foreignholding is the foreign institutional ownership. Trustholding is the domestic investment trust institutional ownership. Dealerholding is the domestic dealer institutional ownership. $t-1$ represents a one-year lag. $\chi^{2}$ is the joint test of estimated coefficients for three subgroups. $\sigma_{\text {Coverage }}^{2}$ is the variance of Coverage. $\pi$ and $\mu$ is the marginal probability and mean for the $j$ th latent subgroup. ${ }^{\dagger}$ denotes the delta-method standard error. Asterisks ${ }^{* * *},{ }^{* *},{ }^{*}$ indicate significant levels of $1 \%, 5 \%$, and $10 \%$, respectively. 
results indicate that foreign analysts prefer subgroup 3 to the others and the determinants of foreign analyst coverage are price-to-book ratio and firm size. Finally, I also find that the foreign analysts alter their following in the same direction as ownership of foreign and domestic trust institutional investors.

The AIC and BIC for the mixture model in Table 4 are 4604.903 and 4761.379, respectively, and 4414.57 and 4617.053 for the mixture model, as seen in Table 7. The mixture model based on foreign institutional ownership condition (the mixture model in Table 7) is a favorite mixture model rested on information criterions for model selection. Therefore, without considering the endogenous relationship between foreign institutional ownership and foreign analyst coverage, the results from Table 4 indicate that subgroup 2 is the subgroup with the highest foreign analyst coverage. However, after taking into account the endogenous influence, the results from Table 7 reveal that subgroup 3 is the subgroup with the highest foreign analyst coverage, with different empirical results. In Taiwan, foreign institutional investors are the primary buy-side clients of foreign analyst reports. Changes in foreign analyst coverage of a firm are highly correlated with foreign institutional shareholdings. Therefore, to observe the characteristics of the targets followed by foreign analysts, the foreign institutional ownership cannot be neglected.

\section{Conclusions}

Since financial statements present backward looking information, many investors think that analyst reports have predictive value. Changes in analyst coverage of a firm might be an early indicator of changes in the firm's fundamentals and future stock return performance. Therefore, the firm characteristics that interest the analysts will be of valuable reference for investors. In this study, I examine firm characteristics that influence analyst coverage using data of 366 stocks listed firms on the Taiwan Stock Exchange that were followed by foreign analysts from January 2006 to June 2012.

The results find that mixture model may present the differential influences of the heterogeneity in firm characteristics from different subgroups for analyst coverage. Without considering the endogenous relationship between foreign institutional ownership and analyst coverage, price-to-book ratio and firm size are the key characteristic variables of foreign analyst coverage. And also, price-tobook ratio and foreign analyst coverage may present an inverted U-shaped or a U-shaped correlation in different subgroups. After considering the endogenous relationship between foreign analyst coverage and foreign institutional ownership, the price-to-book ratio and firm size are still the key variables of foreign analyst coverage. Furthermore, changes in foreign analyst coverage of a firm are highly correlated with foreign institutional shareholding. Therefore, to observe the firm characteristics targeted by foreign analysts, the influences from changes in foreign institutional ownership cannot be ignored. Finally, I also find that large-sized firms with high institutional ownership and medium share turnover 
ratio have the highest mean of probability of being followed by foreign analysts

This study focuses on foreign analyst reports, which are highly influential in the Taiwan Stock Market. However, foreign and domestic securities houses have different types of clients in terms of target return, risk preference and investment amount. Thus, in turn, the characteristics of their target firms might also be different. Therefore, to investigate the characteristics that attract domestic analysts or foreign analysts or both is an interesting subject worthy of further investigation in the future.

\section{Acknowledgements}

I thank the anonymous reviewers for their comments of the article and also thank the financial supported from the Ministry of Science and Technology of Taiwan (project no. MOST 105-2410-H-130-005).

\section{References}

[1] Jegadeesh, N. and Kim, W.J. (2010) Do Analysts Herd? An Analysis of Recommendations and Market Reactions. Review of Financial Studies, 23, 901-937.

http://dx.doi.org/10.1093/rfs/hhp093

[2] Jiraporn, P., Chintrakarn, P. and Kim, Y. (2012) Analyst Following, Staggered Boards, and Managerial Entrenchment. Journal of Banking and Finance, 36, 3091-3100. http://dx.doi.org/10.1016/j.jbankfin.2012.07.013

[3] Altınkılıc, O., Balashov, V. and Hansen, R.S. (2013) Are Analyst' Forecasts Informative to the General Public? Management Science, 59, 2550-2565.

http://dx.doi.org/10.1287/mnsc.2013.1721

[4] Call, A., Chen, S. and Tong, Y.H. (2013) Are Analysts' Cash Flow Forecasts Naive Extensions of Their Own Earnings Forecasts? Contemporary Accounting Research, 30, 438-465. http://dx.doi.org/10.1111/j.1911-3846.2012.01184.x

[5] Bradshaw, M. (2009) Analyst Information Processing, Financial Regulation, and Academic Research. The Accounting Review, 84, 1073-1083. http://dox.doi.org/10.2308/accr.2009.84.4.1073

[6] Firth, M., Lin, C., Liu, P. and Xuan, Y. (2013) The Client Is King: Do Mutual Fund Relationships Bias Analyst Recommendations? Journal of Accounting Research, 51, 165-200. http://dx.doi.org/10.1111/j.1475-679X.2012.00469.x

[7] Huang, A.H., Zang, A.Y. and Zheng, R. (2014) Evidence on the Information Content of Text in Analyst Reports. The Accounting Review, 89, 2151-2180.

http://dx.doi.org/10.2308/accr-50833

[8] Barber, B., Lehavy, R., McNichols, M. and Trueman, B. (2006) Buys, Holds, and Sells: The Distribution of Investment Banks' Stock Ratings and the Implications for the Profitability of Analysts' Recommendations. Journal of Accounting and Economics, 41, 87-117. http://dx.doi.org/10.1016/j.jacceco.2005.10.001

[9] Green, T.C. (2006) The Value of Client Access to Analyst Recommendations. The Journal of Financial and Quantitative Analysis, 41, 1-24. http://dx.doi.org/10.1017/S0022109000002404

[10] Guerard Jr., J.B., Markowitz, H. and Xu, G.L. (2015) Earnings Forecasting in a Global Stock Selection Model and Efficient Portfolio Construction and Management. International Journal of Forecasting, 31, 550-560. 
http://dx.doi.org/10.1016/j.ijforecast.2014.10.003

[11] Tehranian, H., Zhao, M. and Zhu, J. (2014) Can Analysts Analyze Mergers? Management Science, 60, 959-979. http://dx.doi.org/10.1287/mnsc.2013.1796

[12] Mola, S., Rau, P.R. and Khorana, A. (2013) Is There Life after the Complete Loss of Analyst Coverage? The Accounting Review, 88, 667-705. http://dx.doi.org/10.2308/accr-50330

[13] Jung, J.H., Pae, J. and Yoo, C.Y. (2015) Do Analysts Treat Winners and Losers Differently When Forecasting Earnings? International Journal of Forecasting, 31, 531-549. http://dx.doi.org/10.1016/j.ijforecast.2014.02.006

[14] Lewellen, W. and Badrinath, G. (1997) On the Measurement of Tobin's q. Journal of Financial Economics, 44, 77-122. http://dx.doi.org/10.1016/S0304-405X(96)00013-X

[15] Lundholm, R. and Sloan, R. (2013) Equity Valuation and Analysis with eVal. 3rd Edition, McGraw Hill Irwin, New York, NY.

[16] Lakonishok, J., Shleifer, A. and Vishny, R. (1994) Contrarian Investment, Extrapolation, and Risk. Journal of Finance, 51, 1715-1742. http://dx.doi.org/10.2307/2329262

[17] Wang, L.H., Cheng, C.C. and Kuo, H.C. (2018) What Does Foreign Securities Houses Concern? Value or Growth? Review of Securities and Futures Markets, 30, Forthcoming. (In Chinese)

[18] McNichols, M. and O’Brien, P. (1997) Self-Selection and Analyst Coverage. Journal of Accounting Research, 35, 167-199. http://dx.doi.org/10.2307/2491460

[19] Young, S.M. and Peng, E.Y. (2013) An Analysis of Accounting Frauds and the Timing of Analyst Coverage Decisions and Recommendation Revisions: Evidence from the US. Journal of Business Finance and Accounting, 40, 399-437. http://dx.doi.org/10.1111/jbfa.12020

[20] Clinton, S.B., Pinello, A.S. and Skaife, H.A. (2014) The Implications of Ineffective Internal Control and SOX 404 Reporting for Financial Analysts. Journal of Accounting and Public Policy, 33, 303-327. http://dx.doi.org/10.1016/j.jaccpubpol.2014.04.005

[21] Chen, T., Harford, J. and Lin, C. (2015) Do Analysts Matter for Governance? Evidence from Natural Experiments. Journal of Financial Economics, 115(2), 383-410. http://dx.doi.org/10.1016/j.jfineco.2014.10.002

[22] Kadan, O., Madureira, L., Wang, R. and Zach, T. (2012) Analysts' Industry Expertise. Journal of Accounting and Economics, 54, 95-120. http://dx.doi.org/10.1016/j.jacceco.2012.05.002

[23] Jung, M.J., Wong, M.H.F. and Zhang, X.F. (2015) Analyst Interest as an Early Indicator of Firm Fundamental Changes and Stock Returns. The Accounting Review, 90, 1049-1078. http://dx.doi.org/10.2308/accr-50912

[24] Hsieh, W.L.G., Lee, C.S. and Wang, C.J. (2013) Target Price Accuracy in Foreign Analysts' Reports for Taiwan Stocks. NTU Management Review, 24, 43-70. (In Chinese) http://dx.doi.org/10.6226/NTURM2013.AUG.R13005

[25] Moses, O.D. (1990) On Bankruptcy Indicators from Analysts' Earnings Forecasts. Journal of Accounting, Auditing and Finance, 5, 379-409.

[26] Arand, D., Kerl, A. and Walter, A. (2015) When Do Sell-Side Analyst Reports Really Matter? Shareholder Protection, Institutional Investors and the Informativeness of Equity Research. European Financial Management, 21, 524-555. http://dx.doi.org/10.1111/j.1468-036X.2013.12028.x

[27] Aggarwal, R., Erel, I., Ferreira, M. and Matos, P. (2011) Does Governance Travel 
around the World? Evidence from Institutional Investors. Journal of Financial Economics, 100, 154-181. http://dx.doi.org/10.1016/j.jfineco.2010.10.018

[28] Hutchinson, M., Seamer, M. and Chapple, L.E. (2015) Institutional Investors, Risk/Performance and Corporate Governance. International Journal of Accounting, 50, 31-52. http://dx.doi.org/10.1016/j.intacc.2014.12.004

[29] Bushee, B.J., Carter, M.E. and Gerakos, J. (2014) Institutional Investor Preferences for Corporate Governance Mechanisms. Journal of Management Accounting Research, 26, 123-149. http://dx.doi.org/10.2308/jmar-50550

[30] Caiazza, S., Pozzolo, A. and Trovato, G. (2016) Bank Efficiency Measures. Journal of Productivity Analysis, 46, 25-41. http://dx.doi.org/10.1007/s11123-016-0470-6

[31] Lubrano, M. and Ndoye, A.A.J. (2016) Income Inequality Decomposition Using a Finite Mixture of Log-normal Distributions: A Bayesian Approach. Computational Statistics and Data Analysis, 100, 830-846. http://dx.doi.org/10.1016/j.csda.2014.10.009

[32] Karlis, D., Papatla, P. and Roy, S. (2016) Finite Mixtures of Censored Poisson Regression Models. Statistica Neerlandica, 70, 100-122.

http://dx.doi.org/10.1111/stan.12079

[33] Compiani, G. and Kitamura, Y. (2016) Using Mixtures in Econometric Models: A Brief Review and Some New Results. Econometrics Journal, 19, C95-C127.

http://dx.doi.org/10.1111/ectj.12068 